Mesned ilahiyat Araştırmaları Dergisi/ Journal of Mesned Divinity Researches ISSN 2667-7075 | e-ISSN 2687-3605 | https://dergipark.org.tr/tr/pub/mesned Cilt (Vol.) 12 Sayı (Issue 1) Bahar - (Spring) 2021

ARAŞTIRMA MAKALESI | RESEARCH ARTICLE

(Bu makalenin intihal içermediği benzerlik tarama programlarıyla teyit edilmiştir. / The similarity that this article does not contain plagiarism, has been confirmed by plagiarism checker programs.)

Doi: $10.51605 /$ mesned.893097

Gönderim Tarihi: 8.03.2021 |Kabul Tarihi: 11.05.2021

\title{
Kıyas İşleminde Teâruz ve Tercîh
}

- Taāruz and Tarjīh in the Practice of Qiyas -

\section{Rifat Yıldız*}

Atıf/Citation: Yıldız, Rifat. "Kıyas İşleminde Teâruz ve Tercîh/ Taāruz and Tarjīh in the Practice of Qiyas". Mesned İlahiyat Araştırmaları Dergisi/ Journal of Mesned Divinity Researches, (Bahar 2021-1): 936.

Öz:

Meydana gelen yeni gelişmeler insan açısından sürekli bir takım yeni sorunun ortaya çıkmasına neden olur. İslam Hukuku da kıyamete kadar geçerli olması hasebiyle ortaya çıkacak yeni problemlere çözüm üretebilecek bir yapıya sahip olduğu kabul edilir. Kur'ân ve Sünnet yeni oluşan meselelerin halli için müracaat edilecek temel iki kaynaktır. Bu iki esas delilde inanç esasları gibi değişime kapalı ahkâm olduğu gibi, zaman ve șartlara göre aralarındaki ortak illet ve sebepler göz önüne alınarak yeni sorunların çözümüne yardımcı olacak hükümler de vardır. Fıkıh ilmiyle ilgili çalışmalar tetkik edildiğinde ta'lil ile ilgili ișlemlerin İslam Hukuk tarihinin her döneminde yapıldığı görülecektir. İlk dönem yapılan fikhî işlemlerde kıyas genelde benzer durum ve akıl gibi mânalarda kullanıldığı için illet teorisi daha sonraki fakihlere göre daha geniş bir sahada kabul görmüștür. Kıyas ișlemi İslam Hukuk ilminin önemli bir delil ve aracı olarak tarihi süreçte çok önemli işlevler ifa etmiştir. Kıyas işlemi fıkıh ilminin oluşmaya bașladığı ilk dönemde daha sade ve esnek bir șekilde işlediğ için meydana gelen yeni meselelere rahatlıkla çözüm bulunurdu. İki mesele arasında bulunan ortak temel bir özellik yolu ile ahkâmı birbirine bağlamak biçiminde yapılan küçük mantıkî önermeler o dönem henüz mevcut değildi. Birtakım nedenlerden ötürü zamanla keyfiliğe engel olmak içtihat faaliyetini bir sisteme bağlamak amacıyla içtihadın en yaygın şekillerinden biri olan kıyas anlayışı bir takım ilke ve kaidelerle sınırlama yoluna gidildi. Tarihi süreç içerisinde bazı fakihler itiraz etmesine rağmen kıyas işlemi bir delil ve yöntem olarak ișlemeye devam etti. Kıyas ișlemini geçerli delil ve yöntem olarak gören fakihler gerekçe olarak bazı ahkâmın ta'lil edilmesini ileri sürdü. Bu fakihlere göre ta'lil faaliyeti nasların ihtiva ettiği ahkâmın maksat ve gayeleriyle ilgili zihnî faaliyette bulunma ameliyesidir. Ta'lil teorisinin ortaya çıkışı durmadan devam edip gelişen olaylara sınırlı sayıdaki naslar aracılığıyla çözüm üretebilme ve yeni meselelerin hükümlerini tespit edebilme fikrinden kaynaklıdır. Özellikle fıkhî sorunların çözümünde temel dayanak olan Kur'ân detaylı bir şekilde tetkik edildiğinde bazı ahkâmın illetinin açık bir șekilde ifade edildiği fakat bunların da sınırlı sayıda olduğu görülecektir. Bu nedenle ta'lil nazariyesi, İslam Hukuk düșüncesinin temel tașlarından bi-

* Dr. Öğretim Üyesi, Muş Alparslan Üniversitesi İlahiyat Fakültesi, r.yildiz@alparslan.edu.tr. Orcid: 0000-0002-3126-7854. 
ri olarak kabul edilmiștir. Zira naslardaki illetin tespiti ile Şâri'in hükümleri vazederken dikkate aldığı esasları belirleme işlemi söz konusudur. Allah'ın teşri ettiği ahkâmın kulların maslahatına yönelik genel ve özel durumları bulunmaktadır. Kulların faydasına yönelik genel esaslar makâsıd diye ifade edilirken, özel esaslar da illet ve hikmet diye izah edilmiștir. Kıyas bazı usûlcülerce șeri’ bir delil olarak kabul edilirken bazı usûlcülere göre de delillerden hüküm elde etme yöntemidir. Kıyas işlemini yöntem olarak kabul eden usûlcülere göre kıyasın dört rüknü mevcuttur. Bunlar asl, fer, illet ve hükümdür. Kıyası şeri' delil olarak gören bazı usûlcülere göre ise kıyasın rüknü sadece illettir. Bu nedenle kıyas işlemini yaparken illeti sağlıklı bir şekilde tespit etmek önemlidir. Bu amaçla illetin sıhhatli bir şekilde tespiti yapılırken fer'de illet olabilecek unsurları seçmek, fer'de illet olamayacak unsurları ayıklamak ya da birbirine denk olan ve çatışan illetler arasında en uygun olanı tercih etmek gerekmektedir. Usûl âlimleri illeti tespit ederken bir takım kıstaslar geliștirdikleri gibi teâruz eden illetleri seçmede de bazı ilkeler belirlemişler. Bu çalışmada Hanefî ve Şâfiî alimlerin biri birine denk illetler arasında oluşan teâruz durumunda yapmış oldukları tercih işleminde gözettikleri esaslar ve tercih nedenleri, usûl eserlerinden tespit edilmeye ve gözettikleri esasların sonuçları ortaya konmaya çalışılacaktır. Yapılan çalışmada farklı yöntemler benimsemiş olan usûlcü ve fakihlerin sorunlara çözüm bulmak için olay ve olguların naslarla irtibatını sahih bir șekilde kurmak adına kıyasın rüknü olan illeti tespit için büyük bir çaba sarf ettikleri görülür. Nitekim bu amaçla ileri sürülen illetin sıhhatini tespit için bir takım eleștiri yöntemi geliștirdikleri ve bu metotlardan birinin de şüphesiz muâraza yöntemi olduğu anlaşllır. Usûlcüler bu yöntemle illetin tespitinde hem dikkat edilmesi gereken hususları açlklar hem de tespit edilen illetler teâruz ettiğinde tercih için uyulacak kıstasları da belirlerler. Bu amaçla teâruzu gidermek için Serahsî gibi bazı Hanefî usûlcüler kendi anlayışları gereği illeti merkeze alıp tercih sebeplerini illet etrafinda inşa ederken Şâfiî usûlcüler de illetin tespit ve teâruzu anında tercih işlemi için kendi usûl kaidelerinden hareketle asıl, fer', illet ve hükümle ilintili bazı ölçütler geliştirirler. Usûlcüler ortaya koymuş oldukları bu kıstaslarla asıllarda bulunan ve illet olabilecek vasıfların doğru olarak tespitine çalışırlar.

Anahtar Kelimeler: İslam Hukuku, Usûl, Kıyas, İllet, Teâruz, Tercîh.

Summary:

The new developments taking place today have caused many new problems for Muslims. It is accepted that Islamic law has a structure that can produce solutions to new problems that will arise due to its validity until the qiyamah. The Quran and Sunnah are the two main sources to be consulted for solving new issues. In these two main references, there are ahkâm closed to change, such as the principles of belief, as well as ahkâm that will help to solve new problems by considering the common 'illahs and causes according to the time and conditions. When the studies on Islamic law are examined, it will be seen that activities related to 'illah / ta'līl were carried out in every period of Islamic legal history. Since qiyas was generally used in the meanings of "similar situation" and "reason" in fiqh studies conducted in the first period, the theory of 'illah was accepted in a wider range compared to the later fuqaha. The practice of qiyas, as one of the important dalils and methods of Islamic law ilm, has performed very useful tasks. Since it was used in a simpler and flexible way in the early periods when Islamic law began to emerge, the new issues arising could be resolved easily. The small logical propositions made to link ahkâm to each other through a common basic feature found between the two issues did not yet exist at that time. For a number of reasons, in time, in order to prevent arbitrariness and link the ijtihad activities to a systematics, some restrictions were made through some rules and principles in the understanding of qiyas; one of the most common forms of ijtihad. Ta'lil activity is the mental activity related to the goals and purposes of the ahkâm contained in the nusus. The emergence of the ta'lil theory stems from the understanding of being able to find solutions to the everdeveloping events through a limited number of nusus and to determine the ahkâm of new issues. Especially when the Quran, which is the basic basis for the solution of fiqhi issues, is examined in detail, it will be seen that the 'illahs of some ahkâm are clearly explained, but they are also limited. For this reason, the theory of ta'lil has been accepted as one of the cornerstones of Islamic Law thought. Because, with the determination of the malady in the verses, it is possible to try to determine the basis that Shari takes into consideration while making the provisions. There are general and special issues regarding the interests of servants in the provisions that Allah imposes. While the general principles for the benefit of the servants are expressed as makâsidu's-sharia, the special principles are described as malady and wis- 
dom. In fact, although it is accepted that illness also includes wisdom, it is accepted that wisdom cannot always be considered as malady because it is not an objective, clear and stable feature in al situations. Comparison is the method of obtaining judgment from the evidence, according to others, while sherry is considered as evidence. Compared to the processors who accept the comparison process as a method, the comparison has four items. These; asl, fer, malady and provision. According to the operators who saw the cut as sherry 'evidence the sake of comparison is just the malady. For this, it is necessary to select the elements that may be a malady. The first processors call the "tahkiku'l-menât", while the second is called "tenkihu'l-menât". The third is called preference in the case of nations' offense. In this study, the principles and reasons of preference of Hanafi and Shafiî jurists in the choices they have made in case of offense between the same provinces and the results of the principles they observe will be tried to be determined. In the study, it was seen that the scholars and jurists, who adopted different methods, made a great effort to identify the illness, which is the pillar of comparison, in order to find solutions to the problems, in order to establish a sound connection between events and facts. As a matter of fact, it has been understood that they developed a number of criticism methods to determine the health of the malady put forward for this purpose, and one of these methods is undoubtedly the "muâraza" method. With this method, the proceduralians explained the points to be considered in the detection of the disease and also determined the criteria to be followed for the preference when the detected maladies occur. For this purpose, Hanafi practitioners such as Serahsî centered illness and built the reasons for their preference around malady in order to eliminate the disorder, while Shafii scholars developed some criteria for the determination and treatment of malady based on their own methodologies. With these criteria, the uslists tried to accurately determine the qualities found in the originals that could be a disease. In this way, the uslists were able to defend the judgments they reached in fiqh as well as basing their own methodology.

Keywords: Islamic Law, Usul/Usool, Qiyas,'Illah, Taāruz, Tarjīh.

\section{GİRIş}

Fıkıh usulüyle ilgili yazılan eserlerde üzerine konuşulan ve tartışılan konulardan biri de kıyastır. Bunun nedeni ise insan ve toplum hayatının sürekli bir değişim halinde olması, yeni olaylara ve olgulara açık bulunmasının yanı sıra nasların sınırlı sayıda olmasıdır. Zerkeşîye (ö. 794/1392) göre Allah, bütün şer'i hükümleri kesin ve net bir şekilde ortaya koymamıştır. Bazı hükümlerin bilinmesi ve anlaşılması için kesin, açık deliller vaz' edilmişken bazılarının delilleri zannî bırakılmıştır. Bunun sebebi ise bütün insanları tek bir görüşe mecbur ederek hayatı zorlaştırmamaktır. ${ }^{1}$ Kur'ân ve Sünnet naslarının sınırlı, icmân da sayılı olması hasebiyle sınırsız sorunlara cevap bulunması, meydana gelebilecek yeni sorunlara naslar çerçevesinde çözümler üretilmesi gerekli görülmüştür. Naslardan aralarındaki bazı benzer özellikler yoluyla ortaya çıkan meselelere çözüm üretmek amacıyla başvurulan yöntemlerin en yaygını ise

${ }^{1}$ Bedruddin b. Bahâdır b. Abdullah ez-Zerkeşî, Bahru'l-muhît fì ușûli'l-fiḳh (Kahire: Dâru's-Ṣafve, 1413/1992), 6/108. 
kıyastır. Bu nedenle kıyas; ictihadın dayanağı, rey'in aslı, fıkıh ilminin ve şer'i yöntemlerin temeli kabul edilmiştir. ${ }^{2}$

Kıyas kelimesi sözlükte "takdir, ölçme, şiddet ve eşitlik" mânalarına gelir. ${ }^{3}$ Sözlük anlamıyla bağlantılı bir şekilde mantık, dil ve fıkıh ilimlerinin her birinde terim olarak farklı mânalara gelecek şekilde kullanılmaktadır. Dille ilgili ilimlerden sarf ve nahivde tümevarım yöntemiyle elde edilen ve ulaşılan ölçüye kıyas denirken, mantık ilminde kıyas, doğruluğu kabul edilen en az iki öncülden zorunlu olarak üçüncü bir önermeye ulaştıran akıl yürütmeyi ifade eder. Cüveynî fıkıh usûlünde kıyasın tam tanımının yapılmasının güç olduğunu belirtmekte ve en yakın tanımın ise Bakıllânî'nin (ö. 403/1013) tanımı olduğunu söylemektedir. Bu tanıma göre kıyas: "Bir hükmün ispatı veyahut nefyi için aralarındaki ortak bir durumdan dolayı bilinenin bilenene hamli." 4 şeklinde ifade edilmektedir. Kıyasın tanımının yapılmasının zorluğu nedeniyle Serahsî ve Pezdevî (ö. 482/1089) gibi bazı usûlcüler tanım yerine kıyasın rükün, şart ve vasfın geçişliliği gibi bir kısım özelliklerini zikrederek konuyu açılamaya çalışmaktadırlar. ${ }^{5} \mathrm{Bu}$ nedenle kıyas genel olarak, "aralarındaki ortak vasfa veya benzerliğe dayanarak, hakkında açık hüküm bulunmayan bir meselenin hükmünü, hükmü açıkça belirtilen meseleye göre belirlemek" şeklinde açıklanmaya çalışılmıştır. ${ }^{6}$ Ayrıca fıkıh çalışmalarında kıyas lafzı, "salt düşünme, doğruya ulaştıran delil" anlamında ve birçok istidlâl çeşidini ifade etmek için kullanıldığı gibi re'y, şer'iatın içeriği akılla anlaşılan ve ta'lil edilebilen kısmı ve genel ilke anlamında da kullanılmaktadır. ${ }^{7}$

Usûlcüler kıyas işlemini işlev yönünden değerlendirirken mensup oldukları mezhep ve takip ettikleri usûl açısından iki gruba ayrılmışlardır. Kıyas iş-

\footnotetext{
2 İmamu'l-Haremeyn Ebu'l-Meâllî Abdulmelik b. Abdullah b. Yususf el-Cüveynî, el-Burhân, thk. Abdulazim ed-Dîb (1399), 2/743; Ebû Hamid Muhammed b. Muhammed b. Muhammed el-Gazzâlî, el-Mustașfa min ilmi'l-uṣ̂ul (Mısır: Matbaatu'l-emîriye, 1334), 2/228.

3 Ebu'l-Fadl Cemaluddîn Muhammed b. Mükrim b. Manzûr, Lisânu'l-'Arab (Beyrut: Dâru Șadr, ), “Kys", 6/187.

${ }^{4}$ Cüveynî, Burhân, 2/745 Gazzâlî, Musțasfa, 2/228.

${ }^{5}$ Ebû Bekir Muhammed b. Ahmed b. Ebî Seh es-Serahsî, Ușûlu's-Serahsî (Beyrut: Dâru Kütubi'lİlmiyye, 1414/1993), 2/143; Fatih Orum, Klasik Fıkıh Kaynaklarındaki Kıyas Anlayışının Kur'an Açısından Değerlendirilmesi (Zâhiru'r-Rivâye Örneği), (İstanbul: İstanbul Üniversitesi, Sosyal Bilimler Enstitüsü, Doktora Tezi, 2008), 53.

${ }^{6}$ Ebû Bekr Ahmed b. Ali er-Râzî el-Cessâs, el-Füsûl fi'l-ușûl (Kuveyt: Vizâretü'l-Evḳâf ve'ş-Şuini'lİslamiyye, 1414/1994), 4/9; Cüveynî, Burhân, 2/747-748; H. Yunus Apaydın, "Kıyas (Fıkıh)", Türkiye Diyanet Vakfi İslam Ansiklopedisi (Ankara: TDV Yayınları, 2002), 25/529.

${ }^{7}$ Cüveynî, Burhân, 2/743; Gazzâlî, Mustașfa, 2/228.
} 
lemini çoğu usulcü şeri' bir delil olarak değerlendirirken ${ }^{8}$ Şirâzî (ö. 476/1083), Cüveynî ve Gazzâlî gibi gibi usûlcülere göre de kıyas delillerden hüküm elde etme yöntemidir. Kıyas işlemini genelde delil ve yöntem olarak kabul eden birçok usûlcüye göre kıyasın dört rüknü bulunmaktadır. Bunlar asl, fer, illet ve hükümdür. ${ }^{9}$ Pezdevî ve Serahsî gibi usûlcülere göre ise kıyasın rüknü sadece illettir ${ }^{10}$

İllet kelimesi sözlükte "kişiyi ihtiyacını gidermekten alıkoyan durum, hastalık, zafiyet, gerekçe ve sebep" gibi mânalara gelir. ${ }^{11}$ Mezkûr anlamların son ikisi kelimenin ıstılahî anlamına daha uygun düşmektedir. İllet kelimesi, daha çok "bulunduğu mahalde değişikliğe yol açan durum" olarak ifade edilir ve insan bedeninde oluşturduğu değişiklik nedeniyle hastalığın bu ismi aldığı belirtilir. ${ }^{12}$ Terim anlamını ifade için birçok tanımı yapılmış olan illet; "hükmü gösteren veya gerekli kılan yahut hükmün kendisine bağlandığı durum, vasıf, mâna, gerekçe" biçiminde ifade edilebilir. ${ }^{13}$

Bir hükmün birden fazla illetle ta‘lilinin yapılıp yapılamayacağı hususu usûlcüler arasında tartışma konusu olmuştur. Bazı detaylarda farklı görüşler ileri sürülse de cumhura göre birden fazla illetle bir hükmün ta'lilili mümkündür. ${ }^{14}$ Örneğin Şirâzîye göre kasten adam öldürme, zina ve dinden dönme durumlarında olduğu gibi şeri’ bir hüküm bir, iki veya daha fazla illetle tespit edilebilir. Aynı şekilde cinsel münasebet yasağı da hayız, ihram, oruç ve itikâf gibi birkaç illetten kaynaklanabilir. Bir hüküm birçok illetle sabit olabildiği gibi birbirine benzer birkaç hükmün bir illetle tespiti de mümkündür. Nitekim ihramla; cinsel ilişki, koku sürünme ve dikişli elbise giyme yasaklı hale gelebilmektedir. Ayrıca bir illetle birbirine benzemeyen farklı hükümlerin tespiti de mümkündür. Buna hayzın; cinsel ilişkiyi, namaz kılmayı ve oruç tutmayı engellemesi örnek olarak verilebilir. Ancak cinsel münasebetin bir kişi hakkında aynı anda hem caiz hem de yasak olması gibi bir illetle birbirine ters hükümleri tes-

\footnotetext{
${ }^{8}$ Serahsî, Ușûl, 2/65-66.

${ }^{9}$ Ebû İshak İbrahim eş-Şirâzî, Şerhu'l-luma' (Beyrut: Dâru Ğarbi'l-İslamî, 1407/1988), 757, 824, 847.

${ }^{10}$ Serahsî, Uș̂ul, 2/174; Alâüddîn Abdülazîz b. Ahmed b. Muhammed el-Buhârî, Keş̧ü'l-esrâr an uṣ̂lli Fahri'l-İslam el-Pezdevî (Beyrut: Dâru Kütubi'l-'Ilmiyye, 1418/1997), 3/501-502.

11 İbn Manzûr, Lisânu'l-'Arab, "'alle", 11/471.

12 Cessâs, Füșûl, 4/9; Serahsî, Uș̂̂l, 2/143-144; İbn Manzûr, Lisânu'l-'Arab, "'alle”, 11/471; İbrahim Kâfi Dönmez, "Illlet”, Türkiye Diyanet Vakfı İslâm Ansiklopedisi (İstanbul: TDV Yayınları, 2000), 22/117.

${ }^{13}$ Cessâs, Fü̈ṣ̂l, 4/9.

${ }^{14}$ Abdurrahman Candan, İslam Hukukunda İlleti Tespit Yöntemleri (Konya: Selçuk Üniversitesi, Sosyal Bilimler Enstitüsü, Doktora Tezi, 2005), 254.
} 
pit etmek doğru olmaz. Bu iki hüküm birbirine zıt olduklarından aynı illetin bu iki hükmü aynı anda gerektirmesi düşünülemez. ${ }^{15}$

Usûlcülere göre birçok mâna illet olabilir. İllet vasıf olabileceği gibi, hüküm de illet olabilir, ayrıca Şirâzî ve Gazzâlî gibi usûlcülere göre isim de illet olabilir. ${ }^{16}$ İllet, hükmün konulma amacının bilinmesine yarayan bir mâna olabileceği gibi hükmün konulma amacını kesin olarak ifade etmeyen bir mâna da olması mümkündür. ${ }^{17}$ Ayrıca illetin, fer'i asla bağlayan, ikisinin de sahip olduğu ortak bir özellik olması gerekir. Hükümlerin illeti, Şâri' tarafından belirlenmiş olabileceği gibi naslardan istinbat yoluyla da elde edilmiş olabilir. Birincisinde illet, Şâri’ tarafından belirlendiği için ayrıca bir illet aramaya gerek yoktur. Şâri' in "şarap/hamr, sarhoş ediciliğinden dolayı size haram kılındı" örneğinde olduğu gibi hamr'ın haramlık illeti nas tarafından tespit edilmiştir. Hamrdaki sarhoş edicilik özelliğinin tespiti ve haramlığın onun dışındakilere aktarımı da istinbat yoluyla olmaktadır. ${ }^{18}$

Şirâzî gibi bazı usûlcülere göre illetler; hükümlere delalet eden emâre, alâmet ve delildir. Bu nedenle illetin tespiti Kitap ve Sünnetle olabileceği gibi âm ve has olan illetlerle de bir şeyde hükmün tespiti yapılabilir. Çünkü nas, icmâ ve te'sîr yoluyla illetin sıhhatini gösteren yol bu iki illette de bulunmaktadır ki bu da her iki illetin doğruluğunu göstermektedir. Ona göre şayet illetten kasit hükme uygunluğu ifade eden mâna ise hükmün bu iki illetten her birine bağlanması da mümkündür. ${ }^{19}$ Bu nedenle kıyas işleminde illeti sağlıklı şekilde tespit etmek önemlidir. Illlet tespit edilmeye çalışılırken; illet olabilecek vasıfları seçmek, illet olamayacak unsurları ayıklamak, birbirine denk olan veyahut çatışan illetlerin arasını uzlaştırmak veya en uygun olanı tercih etmek gerekmektedir. Bu nedenle makalede bazı Hanefî ve Şâfiî fakihlerin birbirine denk illetler arasında oluşan "teâruz" durumunda yapmış oldukları tercihlerde gözettikleri esasları ve tercih nedenleri tespite çalışılacaktır.

Teâruz ve tercihin genelde bütün delilleri kapsayacak şekilde ele alındığı kitap ve makaleler olsa da yapılan araştırmada kıyas işleminde teâruz ve tercih konusunda yazılmış müstakil bir esere rastlanılmadı. Teâruz ve tercih konuları

\footnotetext{
15 Şirâzî, Şerhu'l-luma', 836.

${ }^{16}$ Şirâzî, Şerhu'l-luma', 838; Gazzâlî, Mustașfa, 2/335.

${ }^{17}$ Şirâzî, Şerhu'l-luma', 843; Gazzâlî, Mustașfa, 2/336.

${ }^{18}$ Şirâzî̀, Şerhu'l-luma', 845.

${ }_{19}$ Cessâs, Füșûl, , 4/138-139; Şirâzî, et-Tabșıra fì uṣulli'l-fikh (Dımaşk: Dâru'l-Fikr, 1403/1983), 481. Gazâlî, Mustasfâ, 2/342; Serahsî, Ușûl, 2/174. Ali b. Muhammed Amidî, el-ịhkâm fì uṣûli'l-ahkâm (Riyad: Dâru's-Samîî, 1424/2003), 3/295-296.
} 
genel olarak usûl eserlerinin teâruz, muaraza veyahut teâdül konu başlıklarında ele alınmaktadır. Bazı usûl eserlerinde teâruz ve tercih her bir delil için ayrı ayrı ele alınırken, birçoğunda ise bağımsız bir başlık altında incelenmiştir. ${ }^{20} \mathrm{Bu}$ sebepten farklı usûl anlayışına sahip âlimlerini görüşlerini tespit için konunun çalışılmasının faydalı olacağı düşünülmüştür.

\section{TEÂRUZ}

Teâruz kelimesi sözlükte "çatışmak, birbirine ters düşmek, karşılaşmak, çelişki" gibi mânalara gelirken, ${ }^{21}$ fıkıh usulünde ise aynı düzeydeki iki eşit delilden her birinin, diğer delilin gereğini yapmasını engelleyecek şekilde karşı karşıya gelmeleri anlamına gelir. ${ }^{22}$ Usûl eserlerinde teâruz konusunu ifade için muâraza, teâdül, temânu', tedâfu', tenâkuz, tezâd, tenâfî, ihtilâf gibi lafızlar da kullanılır. Pezdevî ve onun eserinin şârihi Abdülazîz Buhârî (ö. 730/1330)gibi bir kısım usulcünün, tenâkuz için "bazı durumlarda delilin hükmünün bulunmaması", teâruz içinse "iki eşit düzeydeki delilin, aralarını uzlaştırmanın mümkün olmayacağı biçimde karşı karşıya gelmesi" şeklinde farklı bir tanım yaptıkları görülür. Ayrıca "tenâkuz", delilin butlanını gerektiren bir hal iken "teâruz" ise delile ilişmeden ulaşılmak istenen hükmün oluşumunu engelleyen bir durumdur. ${ }^{23}$ Buna mukabil Gazzâlî, teâruzu, tenâkuz olarak da ifade etmiştir. ${ }^{24}$

\subsection{Kıyasta Teâruz}

Hanefî usûl kitaplarının dişındaki usûl eserlerinin çoğunda usûl âlimleri illete yönelik kusurları saydıktan sonra "mumânea" ve "muâraza" konularını ele alırlar. Muâraza konusuna müstakil bir başlık açmayan usûlcüler genelde illete yönelik eleştirileri işlerken doğrudan veya dolaylı olarak teâruzu ele alıp değerlendirirler. Bu eserlerde illete yönelik eleştirilerin büyük bir kısmı muârazayla ilgilidir. Bu nedenle illetin doğru bir şekilde tespitinde illete yöneltilen eleştirilerin iyi tespiti gerekir. Bu eleştirilerin hangileri haklı bir nedene, delile dayanmakta veya yapılan eleştirilerin hangilerinin zayıf, haksız olduğu ortaya

${ }^{20}$ Şükrü Özen, “Teâruz”, Türkiye Diyanet İslam Ansiklopedisi (İstanbul: Türkiye Diyanet Vakfı Yayınları, 2011), 40/ 208.

${ }^{21}$ İbn Manzûr, Lisânu'l-'Arab, "'arḍ'”, 7/167.

${ }^{22}$ Gazzâlî, Mustașfa, 2/226, 395; Buhârî, Keșfü'l-esrâr, 4/75; Özen, "Teâruz", 40/208.

${ }^{23}$ Buhârî, Keş̧ü'l-esrâr, 4/75.

${ }^{24}$ Gazzâlî, Mustașfa, 2/226, 395. 
konmaya çalışılmalıdır. Hanefî usûlcülere göre illete yönelik haklı itirazlar iki şekilde olabilir. Bunlar "mumânea" ve "muâraza" şekilleridir. Bunlar dışındaki eleştiriler ise dikkate alınmaz. Muârazada muallilin/müstedilin ${ }^{25}$ amacı iddia ettiği şeyi delillendirerek hasmını ilzam etmek, muarızın hedefi de muallilin delillerini çürüterek, iddia etiği şeyi reddetmektir. İddianın ispatı ancak öncüllerinin doğruluğu ve itirazlardan salim olduğu ortaya konarak yapılabilir. Bu nedenle muallilin iddiası ancak mumânea ve muâraza yoluyla çürütülebilir. ${ }^{26}$

Tacuddin Sübkî'nin (ö. 771/1370) içinde yer aldığı bir kısım usûlcüye göre illete yönelik bütün eleştirilerin amacı, illetin dayandığı delillerin öncüllerini devre dışı bırakmaya yöneliktir. Hatta ona göre muârazada illeti işlevsiz bırakma çabası da bulunmaktadır. ${ }^{27}$ Amidî (ö. 631/1233) gibi usûlcüler muarâza konusunu müstakil ve daha detaylı bir şekilde ele almış ayrıca "asılda muâraza" ve "fer'de muâraza" başlıkları altında konuyu incelemişlerdir. ${ }^{28}$ İllete yönelik itirazlar hususunda Pezdevî ve Serahsî gibi Hanefî usûlcüler diğerlerinden farklı bir yol izlemişlerdir. Onlar illete yönelik itirazlar başlı̆̆ında illeti "müessir" ve "muttarıd" diye ikiye ayırdıktan sonra bunlardan her birine yöneltilen eleştirileri ayrı ayrı ele alıp incelemişlerdir. ${ }^{29}$

Mâlikî ve Şâfîi âlimler muârazayı kendi anlayışlarına/yaklaşımlarına göre asılda ve fer'de muaraza şeklinde ele almışlardır. Onlara göre asılda oluşan muaraza; itirazda bulunan kişinin, ister müstakil olsun ister müstakil olmasın illet olmaya uygun başka bir mânayı/vasfı ortaya koyması ve bununla mualille itirazda bulunmasıdır. Ta'lilde müstakil mânaya/vasfa; buğdayda riba'l-fadlın oluşumunun illetini yiyecek olma, tartılabilme veyahut saklanıp depolanabilen gıda maddesi olma özellikleriyle muârazada bulunma, örnek verilebilir. Müstakil olmayana da; ta'lile dâhil olan ve illettin bir parçası sayılan bir özellikle asla yapılan muârazadır. Bunun başka örneği de yaralayıcı bir aletle yaralama sonucu oluşan ölüm hususunda kısasın vücupluğuna yapılan muârazayı örnek verebiliriz. Mâlikî ve Şâfiî âlimlere göre fer'deki muaraza ise müstedillin ortaya

\footnotetext{
${ }^{25}$ Muallil veyahut müstedil, kıyas işleminde talilde bulunan kimseyi ifade için kullanılır. Muarız ifadesi de muallilin taliline itiraz edip illeti eleştiren kişiler içi kullanılır.

${ }^{26}$ Adudüddîn Abdurrahmân b. Ahmed el-Îcî, Şerhu'l-'aḍd alâ muhtasari'l-münteha'l-uṣ̂ll̂̀ (Beyrut: Dâru Kütubi'l-İlmiyye, 1421/2000), 339-340; Abdülhekim Abdurrahman Ased es-Sadî, Mebâhisu'tille fi'l-k̦ıyas 'inde'l-uṣ̂llîn (Beyrut: Dâru'l-Beşâiri'l-İslamiyye, 1421/200), 644.

${ }^{27}$ Allame el-Bennânî, Şerḥu 'allametü'l-Bennânî 'alâ şerhii'l-Celâl Şemsuddîn Muhammed b. Ahmed elMahallî alâ cem 'i'l-cevâm'i (Dâru'l-fikr, 1402/1982), 2:331; Candan, İlleti Tespit Yöntemleri, 68-82.

${ }^{28}$ Ali b. Muhammed el-Amidî, el-ịhkâm fî uṣûli'l-ahkâm (Riyad: Dâru's-Samî̂, 1424/2003), 4/112, 124

${ }^{29}$ Ali b. Muhammed el-Pezdevî, Ușûlü'l-Pezdevî (Mîr Muhammed Muhammed Kütüphane Merkezi), 283; Serahsî, Ușûl, 2/232; Sadî, Mebâhis, 644.
} 
koyduğu hükmü çürütücü bir gerekçeyle illete itirazda bulunmaktır. Buna göre "muâraza", müstedilin ortaya koyduğu delilin zıddını ifade eden bir delili veya o delili çürütücü başka bir delili ileri sürmektir. İmâmü'l-Harameyn göre muâraza; eşitlik iddiasıyla hasma muhalefet edip engel olmak veya hasma, getirdiği delilin delaletine denk bir delil sunmak anlamına gelmektedir. ${ }^{30}$

Hanefi bir kısım usûlcüye göre "muâraza"; itirazda bulunan şahsın, muallilin kendi ta'lilinde tespit etmiş olduğu illetin/vasfın delaletini kabul etmekle birlikte hasmının maksadının tersine başka bir delil ileri sürmesidir. Hanefîlerden Abdülazîz Buhârî gibi usûlcüler "muâraza" için, müstedillin delilinin geçerliliğinin devam etmesini kabul etmekle birlikte hükümde ona muhalefet etmektir demişlerdir. İtirazda bulunan kişi, müstedille karşı şöyle bir gerekçelendirmede bulunmaktadır: Senin zikrettiğin vasıf hükme delâlet etse de bende senin vardığın hükmün hilafına delalet eden başka bir delil bulunmaktadır. Bu açıklamalardan anlaşıldığı gibi Abdülazîz Buhârî'ye göre "muâraza" hasmın delilini çürütmeye/geçersiz kılmaya yönelik bir itiraz değil onun vardığ hükmün aksini ispat etmeye yönelik bir itirazdır denebilir. ${ }^{31}$

\subsection{Hanefîler'e Göre Kıyasta Teâruz}

"Müessir" ve "muttarıd" diye ikiye ayrılan illetlerden müessir illet, fasit ve sahih iki yoldan eleştirilebilmektedir. Müessir illetin defedilebildiği iki sahih şekil "mumâne'a" ve "muârazadır". Serahsî ve Abdülazîz Buhârî gibi bazı Hanefi usûlcülere göre "muâraza" da iki şekilde yapılmaktadır. Bunlardan biri "munâkaza" mânasında muâraza bir diğeri de halis muârazadır.

\subsubsection{Munâkaza Mânasında Muaraza}

"Munâkaza mânasında muaraza" isminden anlaşıldığı gibi bu işlemde hem munâkaza hem de muaraza söz konusudur. İtirazda bulunan, muallilin ta'liline ilişmeden onun tespit etmiş olduğu illeti nefyeden farklı bir illet ortaya koyarak muârazada bulunmaktadır. Munâkazada ise itiraz eden, muallilin delilini iptal etme yoluna gitmektedir. Aslında yapılan işlemlere baktı̆̆ımızda "munâkaza" ile "muârazanın" bir arada olması çelişki gibi görülmektedir. Çünkü muârazada muallilin delilinin tespiti uygun görülmekte ve ulaştığı hükmün doğruluğu kabul edilmekle birlikte munâkazada ise delilin geçersizliği ve hükmün olumsuzluğu ifade edilmektedir. Bu hususu Hanefî usûlcülerden Abdülaziz el-Buhârî şöyle açıklamaktadır: "Biz muârazanın mutlak mânada

30 İmâmü'l-Haremeyn el-Cüveynî, el-Kâfiye fi'l-cedel (Kahire, 1399/1979), 412.

${ }^{31}$ Abdülazîz el-Buhârî, Keşfü'l-esrâr , 4/74. 
muallilin delilinin kabulü mânasına geldiğini kabul etmiyoruz. Muâraza şekil olarak hükmü, mâna olarak da delili engellemek ve itirazdan uzak olmadığını ortaya koymaktır. Bu işlem yapılırken de asıl maksat yapılan kıyas işlemini iptal etmektir." ${ }^{2}$

İçinde munâkaza mânası bulunan muârazaya "kalb" denmektedir. Bu mânada yapılan işlemde muarız, mualilin kullanmış olduğu delili onun iddia ettiği hükmün aksine bir delil olarak kullanmaktadır. Kalb işlemi iki şekilde yapılmaktadır. İlkinde, itiraz edilirken muallilin illet olarak ileri sürdüğü delil ve ta'lilde bulunduğu mesele yani malul/asl alt üst edilerek malul/asl illet, illet ise malul yapılmaktadır. Diğer "kalb" işleminde ise muallilin delil olarak kullandığı illet ters yüz edilerek lehine olan illet aleyhine kullanılmaktadır. Muallilin deliline itiraz bulunduğu ve ta'lilinin hilafına bir hüküm ileri sürüldüğü için bu işlem de muâraza olarak kabul edilmektedir. Aynı zamanda bu işlem munâkazadır da çünkü muarız bu yolla muallilin ta'lilini iptal yoluna gitmektedir.

Birinci kalb işlemine örnek olarak Şâfiîler, zina eden kişinin muhsân sayılması için Müslüman olmasını şart olarak görmezler. Bu görüşlerini gerekçelendirirken şöyle demektedirler: Kâfir olan bekârların yüz celdeyle cezaland1rılması için "kâfir olmak" bir cins kabul edilir ve buna dayanarak evli olarak zina eden kâfirlerin Müslümanlara kıyasla recmedilmesi sonucuna varılır. Bunu gerekçelendirirken Şâfiîler, şöyle bir yol izlemektedirler: Celde; bekârken zina edenlerin, recim de evliyken zina edenlerin cezalarının üst sınırıdır. Bekârken zina edenlere cezalarının üst sınırı olan celde uygulamak gerekli görüldüğünden evliyken zina edenlere de zina cezasının üst sınırı olan recm cezası uygulanmalıdır. Bir şey nimet olarak görülüp gereğini yerine getirmek nasıl ki güzel bir hal ise o nimeti kötüye kullanmak ve ona karşı suç işlemek de o derece kötü bir durumdur. Bu nedenle cezası da ağır olmalıdır. Yani bekâr birisi yüz celdeyle cezalandırılıyorsa evlilik nimetiyle beraber bu işi yapan kişinin cezasının daha ağır olması gerekir. Dolayısıyla önümüzde, evliyken zina edenler için recm cezasından başka bir ceza yolu yoktur. Ayrıca şeriat celde cezasının üstünde recm cezası dışında başka bir ceza da vazetmemiştir. ${ }^{33}$

Bu örnekte Şâfiîler bekâra uygulanan celdeyi, evliyken zina edenin cezası olan recm için illet kabul etmişler. Bu ta'lile Hanefî muarız itiraz ederek şöyle demektedir: Müslümanların evliyken zina edenleri recm edildiği için bekârları-

${ }^{32}$ Abdülaziz el-Buhârî, Keş̧ü'l-esrâr, 4/75.

${ }^{33}$ Zerkeşî, Bahru'l-muhît, $5 / 66$. 
na yüz celde uygulanmaktadır. Bu nedenle bekâr olanın celde cezasının, evli olanın recmine illet olarak kullanılmasını kabul etmiyoruz. Belki doğru olanı tersi durumdur. Evli olanın recm edilmesi bekârın celde cezasının illetidir. Hanefîler'in yapmış olduğu bu kıyas işlemi Şâfiîler'in yaptığı işlemin alt üst edilmiş şeklidir. Şafiîler'in belirlediği illet, malul; malulleri de illet konumuna getirilmiştir. Bu şekilde Hanefîler, Şâfiîler'in kıyasına itiraz ederek onu iptal yoluna gitmişlerdir. ${ }^{34}$

İkinci kalb işlemine örnek ise Şâfiîler abdest alırken başı mesh etmek bir rükündür demektedirler. Yüz yıkamaya kıyasla başın üç kez mesh edilmesi, zikredilen gerekçeden dolayı onlara göre sünnettir. Hanefîler buna itiraz ederek şöyle demektedirler: Başı mesh etmek rükündür. Bir rükün tam olarak yerine getirildikten sonra üç kez yapılması gerekmez. Şöyle ki yüz, üç kez yıkandığında yüzün tamamının yıkanmış olduğu kabul edilir. Yıkama işlemi tam olarak yerine getirildiğinde teslis sünnet olmaz. Başı da farz olan miktardan/ölçüden fazla olarak bir kez mesh ederek farz olan yeri kapladıktan sonra mesh ikmal edilmiş olur. Dolayısıyla bu ikmalden sonra teslis sünnet olmaktan çıar. ${ }^{35} \mathrm{Bu}$ işlemde Şâfiîler, asl ve fer'e bakınca ikisinin ortak özeliği olarak rükün olmayı görmekte ve bu rükün oluşu, teslisin sünnet oluş hükmüne illet olarak değerlendirmektedir. Muarız da işlem üzerine yoğunlaşmakta, rükün oluşun üç kez yapmayı değil de ister üç defayla gerçekleşsin isterse kaplamayla gerçekleşsin ikmali gerektirdiğini düşünmektedir. Muarıza göre başı mesh etmek başı istiab/kaplamayla gerçekleştiğinden, bu işlem bir defayla oluşmaktadır. Dolayısıyla Hanefîler'e göre fer'i asıldan fazla olarak hem kaplama hem üç kez mesh etme yoluna gidilmez. ${ }^{36}$

\subsubsection{Halis Muâraza}

Bu muâraza çeşidinde "munâkaza" mânası bulunmamaktadır. Bu muâraza da aslın illeti ve fer'in hükmünde oluşan muâraza şeklinde oluşur. Bu iki kısmın sahih olanı bulunduğu gibi fasit olanları da bulunmaktadır.

\subsubsection{Fer'in Hükmünde Oluşan Muâraza}

Fer'in hükmünde bulunan teâruz beş şekilde oluşur. İlki aynı konuda bulunan illetin hükmünün tersine olan nasa dayalı teâruzdur. Hanefîler örnek olarak abdestte başın meshinin tekrar edilme meselesini verirler. Şâfîiler'e göre

34 Serahsî, Uș̂̂l, 2/238; Abdülaziz el-Buhârî, Keşfü'l-esrâr, 4/77.

${ }^{35}$ Ebû Zeyd Ubeydullah b. Ömer b. İsa ed-Debûsî, Taķvimu'l-edille fî̀ uṣûl'il-fikh (Beyrut: Dâru Kütubi'l-İlmiyye, 1421/2001), 332; Serahsî, Ușûl, 2/240; Abdülaziz el-Buhârî, Keşfü'l-esrâr, 4/77.

36 Serahsî, Uș̂ul, 2/242 
başı mesh etme rükün olduğundan meshin, yıkanan organlarda olduğu gibi üç kez yapılması sünnettir. Hanefîler de itirazda bulunup şöyle derler: Başı mesh, abdestte mesh olduğundan, mesti mesh etme örneğinde olduğu gibi üçer kez mesh etmeye gerek yoktur. Serahsî'ye göre buradaki itiraz yerindedir. Çünkü aynı meselede nasa dayanarak hasmın hükmünün illetinin hilafına bir hüküm ortaya konmaktadır. Bu işlemde taraflar birbirinin yaptığı işlemi geçersiz saymamakta, kendilerinin doğru kabul ettiği başka bir illetle farklı hükme varmaktadırlar. ${ }^{37}$

İkincisi: Yapılan işleme; konu hakkında varılan hükmü kabulle birlikte, o hükme ekleme yapılarak oluşan değişiklikle meydan gelen teâruzdur. Bu konuyu açıklarken Serahsî önceki örnek üzerinden hasmın "rükün olma" illetini kabulü üzerinden muârazada bulunmaktadır. Farz olan mahalde, farz k1lınan miktarın fazlasıyla işlemin yerine getirilmesi durumunda yıkanan azalarda olduğu gibi başı üç kez mesh etmenin sünnet olmayacağını ileri sürer. Ona göre bu işlem, konu hakkında varılan hükmü takrir ve yapılan ek bir değişiklikle oluşmuştur. Buradaki fazlalık tartışmalı konu hakkında bir açıklama görevini görmektedir. Serahsî'ye göre bu iki çeşit teâruz tercih gerektiren doğru/sahih bir teâruzdur. Ona göre muâraza ancak sağliklı/doğru şekilde oluştuğunda tercih yoluna gidilir. ${ }^{38}$

Üçüncüsü: Anlaşmazlık bulunan konuda, yapılan bir değişiklikle meydana gelen ihlal dolayısıyla oluşan teâruzdur. Baba ve dedesi hayatta olmayan küçük kız çocuğun evlendirilmesi meselesinde kimin veli olacağı hususu bu konuya örnek olarak verilir. Hanefîler'e göre kız çocuğu küçük olduğundan onun evlendirilebilmesi için babasının sahip olduğu velayet yetkisi gibi bir velayet gereklidir. Şâfiîler de kız çocuğu küçük olduğundan, ağabeyi nasıl ki kız çocuğun malında velayete sahip olamıyorsa babanın sahip olduğu evlendirme yetkisine de sahip olamaz diye muârazada bulunurlar. Bu muâraza, tartışma konusu olan meselenin konusu değiştirilerek yapılan bir muârazadır. Asıl mesele, küçük yetim kız çocuğunun evlendirilmesinde velinin tespiti meselesidir. Bizzat onu evlendirecek velinin tespiti meselesi değildir. Şâfiîler velayeti nefyederken bizzat şahıs tayiniyle ta'lilde bulunarak muâraza etmektedirler. Onlar bu yolla, asıl tartışma konusu olan küçük kız çocuğu için baba ve dede dışındaki akrabaların velayet hakkının belirlenmesi meselesinde, akrabalardan kıza en yakın kişinin de ağabeyi olduğunu söylemektedirler. Şâfiîler bu itirazla

${ }^{37}$ Serahsî, Ușûl, 2/242; Abdülaziz el-Buhârî, Keş̧ü'l-esrâr, 4/88.

${ }^{38}$ Serahsî, Ușûl, 2/242-243. 
ağabeyin velayet hakkını nefyetmektedirler. Ağabeyin küçük kız kardeşine velayet hakkı ortadan kalkınca ağabey dışındaki diğer akrabaların velayet hakkı da ortadan kalkmış olur. Güçlü olmasa da bu açıdan muâraza yapmanın doğru olduğu görülür. ${ }^{39}$

Dördüncüsü: İlletin konusuyla bağlantılı olması hasebiyle ta'lilde bulunanın tespit etmediği illeti nefyetme veya olumsuz görmediği illeti ispat şeklinde oluşan teâruzdur. Bu işlemde muallilin ulaşmış olduğu hükme itiraz bulunmakta ve muallilin tespit etmiş olduğu hükmün nefyi istenmektedir. Bu husussa Şâfiîler tarafından Müslüman köleyi satın alan gayri Müslim kişinin mülkiyet edinme hakkına yönelik yapmış oldukları itiraz örnek verilmektedir. Hanefîler'e göre Müslüman köle bir mal olarak kabul edildiğinden Müslüman olmayan bir köle gibi kâfir sahibi tarafından satılabildiği gibi satın da alınabilir. Hanefîler bunu söylerken kâfir maliki Müslüman malike kıyas etmektedirler. Şâfiîler, Hanefîler'in yapmış olduğu bu tálile karşı çıkarak gayri Müslim malikin Müslüman köleyi satma hakkına sahip olabilmesi için baştan/ilkten onu satma hakkıyla, sonradan mülkiyetini devam ettirme hakkına sahip olması gerektiğini iddia ederler. Onlara göre gayri Müslim malikin mülkiyet hakkının devam etmediği icmâyla sabit olduğundan sahip olduğu Müslüman köleyi elden çıkarmaya zorlanır. Bu nedenle gayri Müslim ilkten Müslüman bir köleye malik olamaz. Hanefîler bu itiraza şöyle cevap verirler: Yaptığınız bu muâraza örneğinde ta'lilde nefyedilmeyen vasfın ispatı bulunmaktadır. O da satın almanın aslıyla, satın almayla oluşan mülkiyetin devam ettirilmesinin eşit kabul edilmesidir. Bu da ancak söz konusu meseleyle mülkiyetin devamlılığı ve satın almanın başlangıcında bulunan hükmün aynı olduğu ispatlanırsa kabul edilebilir. Bu nedenle muarız kişinin, mülkiyetin devamlılığı ve satın almanın başlangıcının aynı olduğu ön kabulüyle hareket etme hakkı yoktur. Her ne kadar mülkiyetin devamlılığı ve satın almanın başlangıcının aynı olduğu ön kabulüyle bu muârazanın doğru olduğu kabul edilse de detaylı düşünüldüğünde bu şekilde muârazada bulunmanın doğru olmayacağı anlaşılacaktır. Bu nedenle muallilin bu itiraza cevap verip görüşünü savunma yükümlülügü yoktur. ${ }^{40}$

Beşincisi de muallilin illetini tespit ettiği meselenin hükmü dışındaki başka bir meselenin hükmüyle önceki hükmün nefyi ile oluşan muârazadır. Buna örnek kocasının öldüğü zannedilip, ölüm iddetini bekledikten sonra başka bir erkekle evlenen bir kadın, yeni kocasından çocuk doğurduktan sonra 
öldüğü zannedilen ilk koca çıkagelse çocuk kimin sayılacaktır? Ebû Hanife'ye (ö. 150/767) göre çocuğun nesebi ilk kocaya ait olmalıdır. Çünkü ilk koca sahih akit sahibi olduğundan firaş sahibi ${ }^{41}$ de odur. Bu nedenle firaş sahibi olması hasebiyle çocuğun nesebi ona aittir. Muarızlar ise yeni kocayı şahit bulundurmadan fasit akitle evlilik yapan kişi gibi değerlendirip doğan çocuğun nesebinin ona ait olması gerektiğini iddia ederler. Görüldüğü gibi Şâfiîler'in görüşüyle Ebû Hanife'nin görüşü teâruz etmektedir. Bu teâruz; ta'lilde bulunulan meseleyle aynı olmayan, başka bir mesele hakkında hüküm tespitinde bulunarak oluşmaktadır. $\mathrm{O}$ da meselenin şahitsiz nikâha benzetilmesidir. Ebû Hanife'ye göre fasit olanla sahih olan akitler aynı olmadığından, bu iki mesele birbirine kıyas edilemez. Ona göre birinci koca, firaş hakkındaki öncelikten dolayı firaş hakkı devam ettiği sürece nesebe hak sahibi sayılır. Bu nedenle teâruz eden iki görüş arasında tercih yoluna gidilmelidir. Bu meseleyi çözebilmek için öncelikle şu sorulara cevap bulmak gerekir. Birincisi; ikinci koca, hazır firaş sahibi olduğundan asıl firaş sahibi durumunda bulunması ve çocuğun dünyaya gelmesini sağlayan suyun sahibi olması hasebiyle birinci ve sahih firaş hakkına sahip kocaya tercih edilemez mi? İkincisi, birinci kocanın firaş hakkı nesih edilebilir mi edilmez mi? Bu sorulara cevap olarak Ebû Hanife, meselenin tercih yapılabilecek bir mesele olmadığını söyler. Ayrıca ona göre bir şey ancak kendi misli veya daha üstünüyle neshedilebilir. Bu nedenle fasit firaş sahibi, sahihin misli ve üstünü olmadığından onu neshedemez. Muârazada bulunulan şahitsiz nikâh meselesi de konuyla ilgili bir mesele olmadığından yapılan muârazanın aynı konu hakkında olmadığı anlaşılır. Ona göre illetin aslına yapılan muâraza her yönüyle fasittir. Çünkü asılda bulunan başka bir illeti zikretmesi sebebiyle muarızın ta'lili, muallilin zikrettiği ta'lil nedeniyle kesintiye uğruyor. Dolayısıyla asılda bulunan iki vasıftan sadece biri aracılığıyla aslın hükmü fer'e geçebilir. Muarızın zikrettiği vasıf aslın hükmünü eğer fer'e aktaramıyorsa onun vasıtassyla hüküm fer'e geçmiyorsa bu illet geçersizdir. Bu nedenle aslın hükmünü ortaya çıkaramayan, ta'lil yönünden geçersizdir. Ona göre Şâfiîler'in tespit ettikleri illet şayet fer'e geçebiliyorsa da onların tespit ettiği illet, tartışılan konuyla ilgili değildir. Bu durumda bahsedilen illet konu hakkında yok hükmündedir. Daha önce de açılandığı gibi illetin bulunmaması hükmün yokluğunu gerektirmez. Bu nedenle bahsedilen illetin tartışılan hükmün tespit veya nefye-

${ }^{41}$ Firaş yatak, döşek, sergi anlamındadır. Sahibu'l-firaş; cariyeyle cinsel münasebette bulunabilen sahibi veyahut kadının kocası anlamına gelen, ondan faydalanma hakkına sahip kişiyi ifade etmektedir. Bkz. Ebu Velid Süleyman b. Halef b. S’ad b. Eyyub b. Vâris el-Bâcî, Kitâbu'l-münteķâ şerhu Muvatta' (Kahire: Dâru Kütubi'l-'illâmî), 6/8. 
dilmesiyle bir ilgisinin olmadığı anlaşılır. Hakkında ittifak bulunan fer'e geçişken olma, hakkında ihtilaf bulunan fer'e geçişlilikten daha kuvvetlidir. Dolayısıyla tartışılan meseleye geçişi olmayan bir illetle muârazada bulunmanın geçersiz olduğu anlaşılır. Bu tür muârazaya baktığımızda tespit edilmeye çalışılan veya nefiy edilmeye uğraşılan meseleler aynı meseleler değildir. Bu nedenle aynı meselede teâruz vardır diyemeyiz. ${ }^{42}$

Bu konuda şöyle bir çözüm yoluna gidilebilir. Kocalardan biri gaip diğeri de hazır oldukları halde çocuğun her iki kocadan da olduğu iddia edilemez. Normal bir duruma göre nesebin sahih evlilik akdine sahip olan kocaya ait olması gerekirken fiiliyatta biyolojik olarak nesebin, fasit akit sahibi olan ikinci kocaya ait olması gerekir. Çünkü birinci koca gaip ve biyolojik olarak çocuğun babası olmadığından nesep yönünden fasit firaş hakkına sahip olacak; ikinci koca ise hazır ve çocuğun biyolojik babası olduğundan fiili olarak nesep ona ait olacak fakat akit açısından fasit olacaktır. Bu durumda iki fasit durum birbiriyle teâruz edeceğinden fiili olarak biyolojik babaya nesebin isnadı sahih olabilecektir.

\subsubsection{Aslın İlletinde Oluşan Teâruz}

Bu muârazadan maksat itiraz edenin kıyas yapılan asla ilişkin fer'de bulunmayan başka bir illeti zikredip hükmü de ona isnat ederek muallilin illetine itirazla oluşan muârazadır. Aslın illetinde oluşan teâruz da üç çeşittir.

İlki asılda bulunup fer'e geçişi olmayan illetin zikredilmesiyle oluşan teâruzdur. Bunun örneği muallilin; demirin demir karşıllı̆ı̆nda, birinin diğerinden fazla olarak satışını, tartılan maddeler olması hasebiyle altın ve gümüşe k1yasla satışının caiz olmadığını söylediğinde oluşan teâruzdur. Muarız kıyas yapılan aslın (altın-gümüş) illetinin semeniyet (para olma) olduğunu, tartılabilme özelliğinin olmadığı şeklinde itiraz eder. Demirde bu özellik bulunmadığından bu satımın caiz olacağı yönünde itirazda bulunur. Bu muâraza muallile göre geçersizdir. Çünkü muarız geçişlilik özelliği bulunmayan bir vasıfla tálilde bulunduğu için ta'lili geçersizdir. Muallile göre asılda hükmün tespiti, illetle değil nasla olduğundan, kasır illetle hükmün tespiti gerekli değildir. Geçişlilik özelliği bulunmayan vasfın illet olarak kullanılması uygun olmadığından bununla ta'lilin

${ }^{42}$ Debûsî, Taķvimu'l-edille, 336-338; Serahsî, Ușûl,2/243-244; Abdülaziz el-Buhârî, Keşfü'l-esrâr, 4/8892. 
faydası da yoktur ve bu tálil şekli doğru da olmadığından bu kısımda muâraza oluşmaz. ${ }^{43}$

İkincisi, hakkında ittifak bulunan, fer'e geçişi olan illeti zikrederek asılda meydana getirilen teâruzdur. Bunun örneği muallilin; ölçülebilen mal cinsinden oluşu, illet olarak kabul edip kirecin kireç karşıllğında bir tarafta fazlalık bulunacak şekilde satışın yasak olduğunu ancak eşit olmaları durumunda satışlarının caiz olacağını ileri sürmesidir. Muallile göre kirecin durumu buğday ve arpanın durumu gibidir. Muarız bu duruma itiraz ederek buğday ve arpadaki faizlik illetinin tartılabilme değil yiyecek veya iddihâr/depolanabilme özelliğinin olduğunu, bunun fer'de bulunmadığını ileri sürerek kirecin biri birine karşılık bir tarafta fazlalık bulunacak şekilde satışının caiz olduğunu iddia eder. Bilindiği gibi yiyecek ve depolanabilme gibi özellikler pirinç, darı, mısır, susam, mercimek gibi haklarında icmâ bulunan fer'lerde bulunmaktadır.

Üçüncüsü, hakkında ihtilaf bulunan fer'in hükmüne, geçiş özelliği bulunan illeti zikrederek asılda oluşan muârazadır. Buna örnek, muarızın önceki örneğe itiraz ederek asıldaki yasaklığın illetinin tartılabilme değil yiyecek olma özelliği olduğunu ve bunun da fer'de bulunmadığını söyler. Ona göre bu özellik, hakkında ihtilaf bulunan meyvelerde de söz konusudur. ${ }^{44}$ Dolayısıyla bu muâraza uygun bir itiraz değildir.

$\mathrm{Bu}$ aslın illetinde oluşan muâraza şekli; zikredilen üç çeşidiyle geçersiz muâraza şeklidir. Çünkü muallil ile muarızın, ta'lil sırasında ileri sürmüş olduğu illetler biri birinden farklıdır. Aslın hükmü bir veyahut daha fazla vasıfla tespit edilebildiğinden bu ikisinin ileri sürdüğü vasıflar biri birini engellemez ve nefyetmez.

\section{3. Şâfiîler'e Göre Kıyasta Teâruz}

Şâfiî usûlcülerin çoğu muârazayı ikiye ayırmaktadırlar. Bunlar asılda oluşan teâruzla yapılan muâraza ve fer'de meydana gelen muârazadır. Zerkeşî, bu iki çeşide bir üçüncüyü de eklemektedir. Ona göre bir diğer muâraza da vasıfta oluşan muârazadır. ${ }^{45}$ Amidî ise bu tür muârazayı asılda oluşan teâruz

${ }^{43}$ Debûsî, Takvimu'l-edille, 338; Serahsî, Uș̂̂l, 2/244; Abdülaziz el-Buhârî, Keșfü'l-esrâr, 4/92-95.

${ }^{44}$ Debûsî, Taḳvimu'l-edille, 338; Serahsî, Uș̂ul, 2/244; Abdülaziz el-Buhârî, Keşfü'l-esrâr, 4/92-95.

45 Abdulmelik b. Abdullah b. Yusuf el-Cüveynî, Burhân fî ușûli'l-fikh (Katar: 1399), 2/1066-1068; Amidî, İhkâm, 4/112, 124: Zerkeşî, Bahru'l-muhît, 5/334. 
konusu içinde değerlendirmekte farklı bir başlıkta ele alınmasını uygun görmemektedir. ${ }^{46}$

\subsubsection{Aslın İlletini Tespitte Oluşan Teâruz}

Asılda meydana gelen muâraza, itiraz edenin ister müstakil ister müstakil olmasın asılda hükmün tespitine uygun bir mânayı illet olarak ortaya koyarak yapmış olduğu itirazdır. Şöyle ki itirazda bulunan kişi muallilin ta'lilde bulunduğu asılda tespit etmediği, fer'de de bulunmayan bir illetin asılda bulunduğunu ve aslın hükmünün de buna bağlı olduğunu iddia eder. Hükmün de hasmın belirlediği illetten kaynaklanmadığını ileri sürer. Şâfiîler, Ramazan ayının farz orucu için imsaktan önce niyet edilmesinin gerekliliğiyle ilgili görüşlerini savunurken bu türden örnek verirler. Hanefîler'e göre farz oruca niyet etme süresi zeval vaktine kadar devam etmektedir. Onlara göre imsak vaktinden sonra zevalden önce niyet getiren kişinin orucu geçerlidir. Bu görüşlerine gerekçe olarak da zeval vaktinden önce nafile oruca niyet edilebilmesini öne sürerler. Nafile oruca bu süre içinde niyet edilebildiğine göre farz orucuna da bu vakitte niyet getirilebilir. Şâfiîler bu ta'lile karşı çıkarak nafile orucun farz orucu için asıl kabul edilemeyeceğini, nafile oruçta zevale kadar niyete izin verilmesinin de kolaylık sağlama amaçlı olduğunu söylerler. Bu nedenle farz oruçların tersine nafile oruçlarda, ibadete başlanmış olsa da zevale kadar niyet getirilmesine izin verilmiştir. ${ }^{47}$

Asla yönelik itirazlara cevap verilip verilmemesi hususunda iki görüş bulunmaktadır. İbn Âkil (ö. 513/1119) gibi usûl âlimleri muarızın yapmış olduğu itiraza cevap verilmesinin gerekli olmadığ görüşüne sahiptirler. Onlara göre bir hüküm, iki veya daha fazla illetle ta'lil edilebileceğinden, yapılan itiraz haklı bile olsa muallilin tespit etmiş olduğu vasfın uygun illete zarar vermeyeceğini ileri sürerler. Bu nedenle mualil, itiraz edene bu hükmün birden fazla illetinin bulunabileceğini bu nedenle ikisinin illetleri arasında bir çelişki bulunmadığını söyler. Aslın hükmünün illetini tespit çalışmasında; muallilin tespit etmiş olduğu illetin geçerlilik şartı, bu illete itirazın bulunmuyor olması değildir. İlletin geçerliliği ancak o illetin gerekli şartları taşıması ve sahih bir şekilde ortaya konmasıyla meydana gelir. Dolayısıyla illetin sıhhati, itiraz edilmemesine değil sahih bir şekilde tespit edilmiş olmasına bağlıdır. İllet hükme delalet eden sahih bir mâna olduğu müddetçe başka etkenler onun sıhhatine engel oluşturmaz. ${ }^{48}$

${ }^{46}$ Amidî, İhkâm, 4/143.

${ }^{47}$ Zerkeşî, Bahru'l-muhît, 5/334.

${ }^{48}$ Amidî, İhkâm, 4/113; Zerkeşî̀, Bahru'l-muhît, 5/334. 
Amidî ve İbn Hâcib (ö. 646/1249) gibi usûlcülerin de yer aldığı çoğunluğa göre yapılan itirazın muallil tarafından dikkate alınması ve cevaplandırılması gerekir. Çünkü muarız tarafından itiraz esnasında ortaya konan illetin kabulü durumunda aslın hükmünü gerektiren geçerli ve müstakil iki illet ortaya çıkacaktır. Bu durumda biri biriyle muarız üç ihtimal söz konusu olacaktır. Buna göre illet ya müstedillin belirlediği vasıftır ya muarızın belirlediği vasıftır veya bu iki vasıf birden gerçek vasıftır. Bu ihtimaller teâruz ettiklerinde sadece bu illetlerden birini illet olarak belirlemek zorlama bir tutum olacaktır. ${ }^{49}$

\subsubsection{Fer'in İlletini Tespitte Oluşan Teâruz}

Fer'de oluşan muâraza, itiraz edenin fer'deki hükme muhalif veya o hükümle çelişecek bir başka hükmü ileri sürmesiyle oluşur. Bu muâraza itiraz eden kişi tarafından ya bir nas ya bir icmâ ya hükmün oluşumuna engel bir mani veya gerekli bir şartın yokluğu durumunda yapılır. İtiraz eden, müstedille senin zikrettiğin vasıf fer'in hükmünü tespite yarıyorsa da bende, tespit ettiğin vasfın zıddına veya o vasfı nakz eden bir vasıf bulunmaktadır.

Müstedillin, karnında taşıdığı çocuk istisna edilerek hamile olan cariyenin satılmasını uygun görmesi, nakza örnek verilmektedir. Müstedil, cariyenin bu satışını; "bu iki sa'dan bir sa' istisna olarak sattım" meselesine kıyas ederek uygun görmektedir. Muarız buna itiraz ederek iki meselenin biri birine kıyas edilmesinin uygun olmayacağını söyler. Bu durumdaki cariyenin satışının uygun olmayacağının gerekçesi olarak "cariyenin tamamının satılıp elinin bu satıştan istisna edilemeyeceği" meselesini zikreder.

Zıt vasıfla muârazada, muallil vitir namazını, namazda teşehhüde kıyas ederek hükmünün vacip olduğunu iddia eder. Gerekçe olarak Hz. Peygamber'in bu ikisini sürekli yerine getirip hiç terk etmediğini söyler. Şâfiîler bu k1yasa itiraz ederek vitrin teşehhüde değil sabah namazının sünnetine kıyas edilmesinin daha uygun olacağını ve hükmünün de sabah namazının sünneti gibi müstehap olduğunu söylerler. Gerekçe olarak bu iki namazın ortak illetinin belirli bir vakitte bir farza bağlı olarak kılınıyor olmasıdır. Yani sabah namazının sünnetinin sabah vaktinde, vitir namazının da yatsı vaktinde kılınmasıdır. Ayrıca şer'de bir vakitte iki farz/vacip namazın emredildiği nakledilmemiştir. ${ }^{50}$ $\mathrm{Bu}$ konuya yapılan itirazın cevaplandırılıp cevaplandırılmaması hususunda

${ }^{49}$ Amidî, İhkâm, 4/113; Zerkeşî, Bahru'l-muhît, 5/334; İcî, Şerhư'l- 'Aḍud, 355.

${ }^{50}$ Ebû Hamid Muhammed b. Muhammed b. Muhammed el-Gazzâlî, Menhûl min t'alîkâti'l-uș̂ul (Beyrut: Dâru'l-fikr, 1419/1998), 521-522; Amidî, İhkâm, 4/124; Zerkeşî, Bahru'l-muhît, 5/339; İcî, Şerhu'l-'Aḍd, 358. 
Gazzâlî gibi bazı usûlcüler itiraza cevap verilmesi gerektiği, müteahhir bir k1sım usûlcüler de cevap verilmesi gerekmediği görüşünü ileri sürmektedirler. ${ }^{51}$

\section{TERCÎH}

Sözlükte tercîh kelimesi "bir şeyi başkasından üstün tutmak, tartmak, yeğlemek" anlamına gelmektedir. Amidî, Zerkeşî, ve İcî (ö. 756/1355) gibi usûlcüler tercihin tanımı için delilleri dikkate alarak "bir tarafın ağır basması" şeklinde bir kayıtta bulunurken Serahsî ve Abdülaziz Buhârî gibi bazıları da tercih yapanı vurgulayarak "bir tarafın ağır bastığının açıklanması ve izhar edilmesi" türünden bir yaklaşım benimsemişlerdir.52 Istılahta ise fikıhta ispat vasıtaları, fıkıh usulünde ise deliller arasında teâruz oluştuğunda bir emâreye binaen bir tarafı destekleme, onu üstün görme ve yeğlemeye denir. İspat vasıtasına veya tercih edilen delile râcih, tercih edilmeyip terk olunana mercûh, delillerden birinin güç kazanmasını sağlayan ilâve özelliğe rüchân (müreccih) denilir. Usûl ve fıkıh eserlerinde rüchânı ifade için üstünlük, emâre, kuvvet, meziyet ve ziyade kelimeleri de kullanılır. ${ }^{53}$

Bir kısım delillerin atıl bırakılabileceği endişesiyle tercih yönteminin geçerliliği sorgulanmıştır. Buna rağmen usûlcülerin cumhuru teâruz şartlarının bulunması ve teâruz eden delillerin arası herhangi bir şekilde uzlaştırılamaması durumunda tercihe başvurulabileceğini kabul etmişlerdir. Tercih farklı düzeydeki deliller arasında gerçekleşmez. Cumhura göre eşit düzeyde bulunan delillerden güçlü emâre taşıyanın üstün olacağından onunla amel edilebileceği tezi savunulmuştur. Ayrıca sahâbe ve sonradan gelen fakihlerin, Resulullah'tan (s.a.s) nakledilen rivayetler arasında teâruz gördüklerinde tercih yöntemine başvurularını da tercih için dayanak olarak ileri sürmüştür. Bunun yanı sıra bir takım vasıflarla üstün olanın olmayanla aynı kabul edilip tercihe başvurulmaması aklın ilkeleriyle de uyuşmamaktadır. Ebû Ali el-Cübbâî (ö. 303/916), Bâkıllânî, Ebû Hâşim el-Cübbâî (ö. 321/933) ve Şehâbeddin el-Karâfî (ö. 684/1285) gibi âlimlerce teâruz durumunda muhayyerliğin devreye gireceği ve tercihe başvurulmadan delillerden herhangi biriyle amel edilebileceği görüşü

51 Amidî, İhkâm, 4/124-125; Zerkeşî, Bahru'l-muhît, 5/340; Adud, Şerhu'l-'Adud, 358-359.

52 Serahsî, Ușûl, 2/249; Abdülaziz el-Buhârî, Keşfü'l-esrâr, 4/110; Amidî, İhkâm, 4/291; Zerkeşî, Bahru'l-muhît, 6/130; Adud, Şerhu'l-'Adud, 393; Şükrü Özen, "Tercih". Türkiye Diyanet İslam Ansiklopedisi (İstanbul: Türkiye Diyanet Vakfı Yayınları, 2011), 40/484.

${ }^{53}$ Serahsî, Ușûl, 2/249; Abdülaziz el-Buhârî, Keş̧ü̈l-esrâr, 4/110; Amidî, İḥkâm, 4/291-292; Zerkeşî, Bahru'l-muhị̂t, 6/130-131; Adud, Şerhu'l-'Aḍud, 393-394; Özen, “Tercih”, 40/484. 
kabul edilir. ${ }^{54}$ Zira bu durumda her hâlükârda şer'i bir delile göre hareket edilmiş olur. Ayrıca tercih sonucunda terk edilip, amel edilmeyen delil de geçersiz hale getirilmemiş sayılır. ${ }^{55}$

Deliller arasında tercih yöntemine başvurulabilmesi için bazı şartların bulunması gerekir. Bu nedenle tercihte bulunulacak delillerin ihtimale açık olması gerekmektedir. Bu sebeple tercih sadece zannî deliller arasında gerçekleşebilir, kesin bilgi ifade ettikleri için kat'i deliller arasında ise tercihe gerek yoktur. Kesin deliller, kendi aralarında; kolay elde edilme, açıklık ve bedihî olma yönünden farklılık arz etseler de bu delillerden elde edilen bilgilerden her biri diğerinden daha güçlü olmayıp tamamı kesin niteliktedir. Diğer yandan zan ile kat'i bilgi aynı düzeyde olmadığından kesin olan delille zannî kabul edilen delil arasında da tercihten bahsetmek olmaz. Buna göre Kitabın ve mütevâtir olan Sünnet'in delâleti zannî ve ihtimale açık kısımlarıyla, âhâd hadis ve kıyas işleminde tercih mümkündür. ${ }^{56}$ Delillerden birinin asıl yönünden değil de vasıf bakımından diğer delilden üstün olması durumunda da tercihe başvurulur. Örneğin; âyet ve hadislerdeki lafızların mânaya delaletleri farklı olduğunda; muhkem olanlar, zâhirle; zâhir olanlar, mücmel lafızlarla karşı karşıya geldiğinde birincileri tercih edilir.

Deliller arasında teâruz oluşturan şartlar tam mânasıyla ortaya çıkınca tercih yöntemine başvurulur. Buna göre tercih işlemine başvurabilmek için güç yönünden aynı düzeydeki deliller arasında mahal, nispet, zaman birliğinin olması ve hüküm karşıtlı̆̆ının bulunması gerekir. ${ }^{57}$ Tercihin yapılabilmesi için ayrıca delilerden birinde diğerine üstünlük sağlayabilecek bir emârenin de bulunması gereklidir. Aksi durumda tercih bilâ-müreccih durumu söz konusu olacaktır.

\subsection{Hanefî Usûlcülere Göre Tercîh}

Debûsî (ö. 430/1039) ve Serahsî gibi Hanefî usûlcülere göre tercîh, aynı düzeydeki deliller arasında illetin aslına bağlı olarak değil vasfındaki bir meziyete bağlı bir fazlalık, güçlü oluşunun ortaya çıkışıyla bir delilin diğerine üstün gelmesidir. İlkin aynı düzeyde oldukları zannedilen iki delil değerlendirildikten sonra bunlardan birinin bir takım özellikler yönünden diğerinden ayrıştı-

${ }^{54}$ Hindî, Nihâyetu'l-viüŝul, 3617

${ }^{55}$ Abdülaziz el-Buhârî, Keșfü'l-esrâr, 4/110.

${ }^{56}$ Pezdevî, Ușûl, 291; Gazzâlî, el-Mustassfa min ilmi'l-ușûl (Misır: Matbaatu'l-emîriye, 1334), 2/392-395;

Alâeddin es-Semerkandî, Mizânu'l-ușûl (Katar: 1404/1984), 730.

${ }^{57}$ Abdülaziz el-Buhârî, Keşfü'l-esrâr, 4/110. 
$\breve{g}$ g/farklılaşttğı anlaşılır. Daha sonra bu ayrıcalık dikkate alınarak güçlü olan illet tercih edilip hüküm ona bağlanır. Bu usûlcülere göre baştan bir illetin, hükmü gerektirici olduğu biliniyorsa bu illet hususunda tercih işlemi düşünülemez. Çünkü tercih ancak tereddütlü illetler arasında gerçekleşir. Aynı düzeyde illetlerden birinin birden fazla illetle destekleniyor olmasıyla diğerinin az sayıda illetle destekleniyor olması arasında tercih sebebi olma bakımından bir fark yoktur. Ancak illetlerden biri bazı özellikler bakımından diğerinden daha güçlü olduğu ortaya konabilirse tercih söz konusu olabilir. 58

Tercih konu başlığı altında genellikle kıyaslar arasında illet yönünden tercih sebepleri olarak; illetin tesiri, kendisine şahitlik ettiği hükme delaletinin istikrarı ve devamlılığı, dayandığı asılların çokluğu ve illetin yokluğunda hükmün bulunmaması şeklinde dört özellik zikredilmektedir. Bu usûlcüler Kitap, Sünnet ve icmâ delilleri arasındaki tercih ölçütlerinin hem metin hem de senet yönünden bu bahislerin ele alındığı bölümlerden çıkarılabileceğini ileri sürmektedirler. ${ }^{59}$

Hanefî usûlcülerden Serahsî, tercih sebebi olan ve tercihi gerektiren özellikleri zikrettikten sonra geçersiz tercih şekillerini açıklama yoluna gider. Ona göre fasit tercihler dört şekilde gerçekleşir. Bunlardan ilki bir kıyasın başka bir kıyasla tercihi veya iki kıyastan birinin bir hadisle tercih edilmesidir. Gerekçe olarak ise Serahsî, "hadisin olduğu yerde kıyasa gidilmez" demektedir. Bu nedenle bir mesele hakkında hadis olduğunda kıyas terk edilir. İkincisi ise benzerliklerin çokluğuyla yapılan tercihtir. Ona göre birçok illetin varlığıla bir illetin varlığı etki olarak ayn derecededir. Bu nedenle benzerlik yönünden; birçok yönden benzeyen illetle birkaç yönden benzeyen illet aynı derecededir. Üçüncüsü illetin umum ifade ediyor oluşuyla yapılan tercihtir. Serahsî̀ye göre illetin âm veya hâs oluşu hükme ulaşmak için engel değildir. İlletin gücü; hükme etkisine göredir, âm veyahut hâs oluşuna göre değildir. Âmın hükmü hâssa, hâssın hükmü de âma verilebilir. Bu nedenle âm veya hâs oluş tercih hususuna etkide bulunmaz. Dördüncü fasit tercih, vasıfların azlığı ile yapılan tercihtir. Dolaysıyla birçok vasfa sahip olan illetle bir veya birkaç vasfa sahip illet arasında hükme etki bakımından fazladan bir özellik bulunmamaktadır. ${ }^{60}$ Bu konuda Hânefî usûlcülerin görüş birliği içinde olmadıkları, konuyla ilgili farklı görüşlerin bulunduğunu söylemek de mümkündür. ${ }^{61}$

${ }^{58}$ Debûsî, Takvimu'l-edille, 339; Serahsî, Ușull, 2/250; Abdülaziz el-Buhârî, Keșfü'l-esrâr, 4/114.

${ }^{59}$ Debûsî, Taḳvimu'l-edille, 340; Serahsî, Ușûl, 2/262; Abdülaziz el-Buhârî, Keşfü'l-esrâr, 4/119.

${ }^{60}$ Serahsî, Uș̂̀l, 2/264-265.

${ }^{61}$ Cessâs, Füṣ̂ll, 4/209-210. 
Kıyaslar arasında gerçekleşen tercih nedenlerinin çokluğu ve elde edilmek istenen hükmün illete oranla daha önemli olması hasebiyle genelde Hanefî usûlcüler eserlerinde illete dayalı olan tercih sebeplerinden sadece dört sahih ve dört fâsid olanını ele alıp değerlendirmişlerdir. ${ }^{62}$

\subsection{Hanefî Usûlcülerin Tercih Örnekleri}

Makalenin sınırlarını aşmamak adına konuyu açılamaya yönelik örneklerin bir kısmını vermeye çalışacağız. Örnekleri özellikle Debbûsî (ö. 430/1039) ve Serahsî gibi usûlcülerin eserlerinden vermeye çalışacağız. Hanefî usûlcüler abdest sırasında Şâfiîler'in başın üç kez meshinin sünnet oluşuyla ilgili görüşlerini değerlendirirken başvurdukları ölçütlerden biri illetin tesiri şartıdır. Onlara göre başın meshi sırasında bir kez mesh etmenin yeterli oluşunun delili mest üzerine mesh örneğidir. Çünkü mest üzerine mesh vasfı, mesh ile yıkama vasfı arasında kolaylaştırma prensibi açısından, farklılaşan bir özelliktir. Mesh, y1kamadan daha kolay olduğundan mesh sırasında organın bir kısmının mesh edilmesi, mesh vasfının hükme tesirini ortaya koymaktadır. Dolayısıyla Şâfiîler'in başı mesh, yüz yıkama gibi bir rükündür bu nedenle üç kez mesh edilmesi sünnettir görüşü yıkama işlemine benzediğinden illet olarak hükme etkisi yoktur. ${ }^{63}$

Serahsî, illetin şahitlik ettiği hükmün sebatının kuvvetiyle ilgili tercih hususunda başın mesh edilmesi örneğini yinelemektedir. Teyemmüm, mest üzerine mesh, caiz görenlere göre çorap üzerine mesh ve yara üzerine sarılmış sarg1 üzerine mesh meselesinde, yükümlülüğü hafifletmek amaciyla mesh işleminin tekrarı gerekmemektedir. Ayrıca "rükün" olmayla yapılan ta'lille hükmün sürekliliği arasında bağ bulunmamaktadır. Hâlbuki namazda bulunan kıyam, rükû ve secde gibi rükünlerin tekrarı değil tam olarak yerine getirilmesi istenmektedir. Dolayısıyla rükün oluş vasfının başın üç kez mesh edilmesi yönünde sabit bir vasıf olmadığı ortaya çıkmaktadır. ${ }^{64}$

Dayandığı asılların çokluğu meselesine Debbûsî, rivayet edilen hadislerin râvi sayılarının çokluğu örneğini vermektedir. Ona göre ravi sayısı fazla

62 Abdülalî b. Muhammed b. Nizammuddin el-Ensârî, Fevâtihu'rr-rahamut (Mısır: Matbaatu'lEmîriye, 1334), 2/324-325.

${ }^{63}$ Debûsî, Taķvimu'l-edille, 345; Serahsî, Ușûl, 2/258.

${ }^{64}$ Serahsî, Ușûl, 2/258. 
olan bir hadis, râvi sayısı az olana tercih edilecektir. Çünkü râvi sayısı fazla olan hadisin sahih olma ihtimali daha yüksektir. ${ }^{65}$

Serahsî, illetin yokluğunda hükmün de bulunmaması şartının, en zayıf tercih yöntemi olduğunu söylemektedir. Serahsî konuyla ilgili başın mesh örneğini yinelemektedir. $\mathrm{O}$, rükünle ta'lil yerine, meshle ta'lilde bulunulmasının daha doğru olacağını iddia eder. Çünkü tekrar etme hükmünün devamlılığı, rükün olmayışla ortadan kalkmamaktadır. Nitekim mazmaza ve istinşak rükün olmadıkları halde tekrar etme hükümleri sürmektedir. ${ }^{66}$

\subsection{Sâfiî̀ Usûlcülere Göre Tercîh}

Şâfiî usulcüler, kesin deliller arasında teâruz bulunmayacağı fikrinden hareketle zannî delil olan haber-i vahid ve kıyasların tercihi konusuna yer vermişlerdir. Onlara göre aynı düzeyde olmayan deliller arasında teâruz olmayacağından aralarında tercih de söz konusu olmayacaktır. Şirâzî'ye göre asılların delilleri ve illetleri örneğinde olduğu gibi kesin ilim gerektiren iki delil ve iki illet arasında tercih gerçekleşmez. Tercih iki delilden birinin diğerine karşı gücünü açıklamaktır. Kesin bilinen bir konu hakkındaki ilim artıp çoğalmayacağı için tercih ancak tereddütlü zannî deliller arasında olabilir. ${ }^{67}$ Ayrıca kesin bilgi ifade eden deliller arasında bir teâruz oluşmadığından onlar için de tercih söz konusu olamaz. Bu nedenle kesin bilgi ifade eden delillerle zan ifade eden deliller arasında tercih söz konusu değildir. Çünkü zan, kesin bilgi karşısında bir değer ifade etmediğinden aynı düzeyde sayılmazlar. Zerkeşı̂’ye göre tercih, doğru olanın uygunluğunu ve doğrulunu tespit, yanlış olanın geçersizliğini ortaya koymaktır. ${ }^{68}$

Bir kısım Şâfiîler; teâruz eden delillerden birinde bulunup da diğer delile karşı üstünlük ifade eden her özelliğin tercih sebebi olabileceğini belirtmişlerdir. Buna rağmen hangilerinin tercih sebebi sayılacağı hususunda görüş birliğine varamamışlardır. Bu usûlcülere göre kıyaslar arasında teâruz oluştuğunda teâruz ya kıyasın rükünlerinden asla, ya fer'e, ya illet veya hükme dayalı bir hususla tercih yapılarak giderilir. Bazen tercih rükünler dışında ulaşılan bir gerekçeyle de yapılır. ${ }^{69} \mathrm{Bu}$ nedenle Seyfeddin el-Âmidî, kıyasın bütün rükünle-

\footnotetext{
${ }^{65}$ Debûsî, Takvimu'l-edille, 345.

66 Searahsî, Ușûl, 2/261.

${ }^{67}$ Şirâzî, Șerhu'l-luma',950.

${ }^{68}$ Zerkeşî, Bahru'l-muhît, 6/108.

${ }^{69}$ Fahruddin Muhammed b. Ömer b. Hüseyin er-Razî, el-Mahṣ̂ul fi ilmi uṣ̂uli'l-fiḳh (Müessetü'rRisâle) 5/444: Zerkeşî, Bahru'l-muhît, 6/108
} 
rini ve harici bazı hususları dikkate alarak birçok tercih sebebi olabilecek hususları zikredip peşi sıra bu sebeplerin sayılamayacak kadar çok olduğunu söyler. ${ }^{70}$

İlletler arasında teâruz durumunda Şâfiî usûlcülerden Râzî (ö. 606/1210) ve takipçileri, illeti üç faklı özelliğine göre değerlendirerek aralarında tercih yapmaktadırlar. Bunlardan biri illetin mahiyetine göre yapılan tercih, diğeri illetin tespitine delalet eden delile göre yapılan tercih son olarak da illiyetliğine delalet eden husus hasebiyle yapılan tercihtir. ${ }^{71}$ Illetin tespitinde; illete delalet yönünden tercihte, mukaddimeleri yakine dayalı olan illet, zanna dayalı olana tercih edilir. İlletin tercihiyle ilgili üçüncü durum ise illetin illiyetliğini gösteren yollarla ilgilidir. Bu açıdan tercih de naklî ve aklî diye ikiye ayrılmaktadır. Nakli olanlar: Nas ve ima yoluyla illete delalet eden lafizlarla yapılan tespittir. Nasla yapılan tespitte; "bu illet dolaysıyla", "bu nedenle" veyahut "bunun için" ifadeleri illetin tespitinde diğer yollardan daha önceliklidir. İma yoluyla tespit edilen illet de münâsebe; deveran ve sebr gibi akli yönü ağır basan yollarla tespit edilen illetten daha önceliklidir.72 Ayrıca Şirâzî ve Zerkeşî gibi bazı Şâfî̂ usûlcüler yukarıda saydığımız şartların dışında başka hususların da tercihte göz önünde bulundurulması gerektiğini ileri sürmüşlerdir. ${ }^{73}$ Örneğin illetlerden birinin nasla belirtilmiş diğerinin de istinbâtla tespit edilmiş olması halinde nasla tespit edilen illetin daha uygun olacağı söylenmektedir. Ayrıca illetlerden birinin olumlu bir sıfat olması diğerinin olumsuz bir sıfat olması durumunda olumlu olanın daha uygun olacağından tercih edilmesi gerektiği ifade edilmiştir. Bir diğer şart olarak da illetlerden birinin vasfının isim olması diğerinin sıfat olması durumudur. Şirâzî̀ye göre illetin vasıf/sıfat olması isim olmasından daha uygundur. ${ }^{74}$

\footnotetext{
${ }^{70}$ Râzî, Mahșûl, 5/397; Amidî, İhkâm,4/349; Zerkeşî, Bahru'l-muhît, 6/180.

${ }^{71}$ Râzî, Mahṣ̂ul, 5/444-460; Amidî, İhkâm, 4/349; Ebû Abdullah Safiyyüddin Muhammed b. Abdirrahim b. Muhammed el-Hindî, Nihâteyetu'l-vüssûl fì dirâyeti'l-uṣûl (Mekke: el-Mektebetü't-Ticâriyye), 3757-3762; Tâcuddin Abdulvahhab b. Ali es-Sübkî, Cem'u'l-cevâmi' (Beyrut: Dâru Kütubi'l-İlmiyye, 1424/2002), 116-117.

72 Râzî, Mahșûl, 5/444-460; Kâdî Nasıruddin Abdullah b. Ömer el-Beydâvî, Minhâcü'l-vușûl ilâ ilmi'lușûl (Beyrut: Dâru İbn Hazm, 1429/2008), 245.

73 Şirâzî̀, Şerhu'l-luma', 959; Ebü'l-Muzaffer Mansûr b. Muhammed b. Abdilcebbar es-Sem'ânî, Kâva'ti'u'l-edille fi'l-uṣ̂ul (Beyrut: Dâru Kütubi'l-İlmiyye, 1418/1997), 2/236.; Zerkeşî, Baḥru'l-muhị̂t, 6/181-186.

${ }^{74}$ Şirâzî, Şerhu'l-luma', 951-964.
} 


\section{4. Şafîi Usûlcülerin Tercih Örnekleri}

Bu örneklerden biri; illetlerden birinin sıhhati Kitab ve icmâ ile kesinleşmiş olan bir asla dayanması diğer illetinse bu kesinlikte olmamasıdır. Bu kısma dilsiz kişinin lianının, yeminine kıyas edilmesi örneği verilmiştir. Nitekim Şirâzî'ye göre dilsizin yemininin geçerli olduğu, icmâ ile sabittir. Hanefîler ise kıyaslarında lianı, şahitliğe kıyas etmişlerdir. Şirâzî’ye göre dilsizin şahitliği konusu ihtilaflı bir meseledir ve bu konuda icmâ bulunmamaktadır. Bu nedenle kıyaslarında dayandıkları asıl kesinleşmiş icmâyken Hanefîler'in dayandıkları asıl ise icmâ değildir. Bu nedenle Şirâzî, yaptıkları tercihin daha doğru olduğunu savunmaktadır. ${ }^{75}$

İlletlerin dayandıkları asıllardan birinin kıyasa konu olması hakkında nas bulunması; diğerinin ise kıyasa konu olmaması hususunda nasın bulunmaması halidir. Şirâzî buna "kişinin ölümüyle hac borcunun düşmeyeceği" örneğini vermektedir. Gerekçe olarak haccı borca kıyas etmektedir. Hanefîler ise meseleyi namaz ve oruca kıyas etmişlerdir. Şirâzi'ye göre kendilerinin kıyası daha uygundur. Çünkü kendilerinin tespit ettiği illet, kıyası nasla belirlenmiş bir asla dayanmakta, Hanefîler'in illeti ise böyle bir delile dayanmamaktadır. Şirâzî̀nin dayandığı delilde Hz. Peygamber konuyla ilgili sorulan soru üzerine: “Babam eda etmesi gereken hacc1 yerine getiremeden vefat etti onun yerine hacetsem olur mu?' Hz. Peygamber ona 'Babanın bir borcu olsaydı ve onu ödemen durumunda ne olurdu dersin, bu ona fayda verir miydi?' O da 'Evet' der. Hz. Peygamber de 'O vakit Allah'ın borcu ödenmeye daha layıktır." cevabını verir. Şirâzî'ye göre Hz. Peygamber bu meselede, haccı borca benzetmiş, ona asıl kılmıştır. Bu nedenle onların konuyla ilgili kıyaslarının daha uygun olduğunu iddia eder. ${ }^{76}$

Şirâzi'ye göre tercih sebeplerinden biri, bir illetin muttarid ve mun'akis olması diğer illetin muttarid olup mun'akis olmaması durumudur. Buna örnek olarak küçük kızın babası ve dedesi dışındaki biri tarafından evlendirilmesi meselesini verir. Şâfiîler kız çocuğunu evlendirmede velayet hakkının illeti kızın malı üzerinde bizzat tasarrufta bulunabilmeyken, Hanefîler'in illeti ise asabe olmaktır. Şirâzi'ye göre Şâfî̀ler'in ta'lili daha doğru bir ta'lildir. Çünkü baba ve dede gibi küçük kız çocuğun malı üzerinde tasarrufta bulunabilen kişi ancak onu evlendirmede de hak sahibi olabilir. Onun malı üzerinde tasarruf yetkisi olmayan onu evlendirme yetkisine de sahip olamaz. Ona göre Ha- 
nefîler'in illeti mun'akis değildir. Çünkü hâkim asabe olmadığı halde küçük kız çocuğunu evlendirebilmektedir. Şirâzi bu görüşünü şöyle gerekçelendirmektedir: "Aks'in illetin geçerliliği hususunda görüş birliği varken tardın geçerliliği konusunda görüş birliği bulunmamaktadır. Dolaysıyla bizim ta’lilimiz daha doğrudur."77

\section{SONUÇ}

Kıyas naslara bağlı hükümlerin genişletilmesi yönünde büyük bir önemi ve işlevi haizdir. Ayrıca bu ilmin öğrenilmesiyle yeni oluşan meselelere benzer yollarla çözümler de üretilebilecektir. Bu çalışmada fakihlerin sorunlara çözüm bulmak için olay ve olguların naslarla irtibatını sahih bir şekilde kurmak adına kıyasın rüknü olan illetin tespiti için büyük bir çaba sarf ettikleri görülmüştür. Nitekim bu amaçla ileri sürülen illetin sıhhatini tespit için bir takım eleştiri yöntemleri geliştirdikleri ve bu yöntemlerden birinin de şüphesiz "muâraza" yöntemi olduğu anlaşılmıştır. Usûlcüler, bu yöntemle illetin tespitinde dikkat edilmesi gereken hususları açıkladıkları gibi tespit edilen illetler teâruz ettiğinde tercih için uyulacak kıstasları da belirlemişlerdir. Bu amaçla teâruzu gidermek için Serahsî gibi Hanefî usûlcüler kendi anlayışları gereği illeti merkeze alıp tercih sebeplerini illet etrafında inşa ederken, Şâfiî usûlcüler de illetin tespit ve teâruzu durumunda tercih işlemi için kendi metodolojilerinden hareketle asıl, fer', illet ve hükümle ilgili bazı kıstaslar geliştirmişlerdir. Bu yolla usûlcüler, kendi metodolojilerini temellendirdikleri gibi für'û-i fıkıhta varmış oldukları hükümleri savunabilmişlerdir.

\section{KAYNAKÇA}

Amidî, Ali b. Muhammed. el-İhkâm fî uṣûli'l-ahkâm. 4 Cilt. Riyad: Dâru's-Samîî, 1. Basim, 1424/2003.

Apaydın, H. Yunus. "Kıyas (Fıkıh)", Türkiye Diyanet Vakfı İslam Ansiklopedisi. 25/529539. Ankara: TDV Yayınları, 2002.

Bâcî, Ebu Velid Süleyman b. Halef b. S’ad b. Eyyub b. Vâris. Kitâbu'l-münteḳâ şerḥu Muvatta'. 9 Cilt. Kahire: Dâru Kütubi'l-'illâmî, 2. Basım.

77 Şirâzî, Şerhu'll-luma', 959. 
Bennânî, Allame. Şerhu 'allametü'l-Bennânî alâ şerhii'l-Celâl Şemsuddîn Muhammed b. Ahmed el-Mahallî alâ cem'i'l-cevâmi'. Dâru'l-Fikr, 1402/1982.

Beydâvî, Kâdî Nasıruddin Abdullah b. Ömer. Minhâcü'l-vuṣûl ilâ 'ilmi'l-uṣ̂ul. Beyrut: Dâru İbn Hazm, 1. Basım, 1429/2008.

Buhârî, Alâüddîn Abdülazîz b. Ahmed b. Muhammed. Keşfü'l-esrâr an uṣ̂uli Fahri'lİslam el-Pezdevî. 4 Cilt. Beyrut: Dâru Kütubi'l-'Ilmiyye, 1. Basım, 1418/1997.

Candan, Abdurrahman. İslam Hukukunda İlleti Tespit Yöntemleri. Konya: Selçuk Üniversitesi, Sosyal Bilimler Enstitüsü, Doktora Tezi, 2005.

Cessâs, Ebû Bekr Ahmed b. Ali er-Râzî. el-Füșûl fi'l-uṣûl. 4 Cilt. Kuveyt: Vizâretü'l-Evkâf ve'ş-Şuini'l-İslamiyye, 1414/1994.

Cüveynî, Abdulmelik b. Abdullah b. Yusuf. Burhân fî uṣ̂uli'l-fıḳh. 2 Cilt. Katar: 1. Basım, 1399.

Cüveynî, el-Kâfiye fi'l-cedel. Kahire, 1399/1979.

Debbûsî, Ebû Zeyd Ubeydullah b. Ömer b. İsa. Taḳvimu'l-edille fî uṣûl'il-fıḳh. Beyrut: Dâru Kütubi'l-'İlmiyye, 1. Basım, 1421/2001.

Dönmez, İbrahim Kâfi. “Illlet”, Türkiye Diyanet Vakfı İslâm Ansiklopedisi. 22/117-120. İstanbul: TDV Yayınları, 2000.

Ebû Dâvûd, Süleyman b. Eş'as es-Sicistânî. Sünenu Ebî Dâvûd. Riyad: Beytü'l-Efkâri'dDevliyye.

Ensârî, Abdülalî b. Muhammed b. Nizammuddin. Fevâtiḥu'r-rahamût. 2 Cilt. Mısır: Matbaatu'1-Emîriyye, 1. Basım, 1334.

Gazzâlî, Ebû Hamid Muhammed b. Muhammed b. Muhammed. Menhû̂l min ta'lîķâti'luṣûl. Beyrut: Dâru'l-Fikr, 1419/1998.

Gazzâlî, el-Musțaṣfa min 'ilmi'l-uṣûl. 2 Cilt. Mısır: Matbaatu'l-Emîriyye, 1. Basım, 1334.

Hindî, Ebû Abdullah Safiyyüddin Muhammed b. Abdirrahim b. Muhammed. Nihâteyetu'vüṣ̂̂l fî dirâyeti'l-ușûl. 9 Cilt. Mekke: el-Mektebetü't-Ticâriyye.

İbn Menzûr, Ebu'l-Fadl Cemaluddîn Muhammed b. Mükrim, Lisânu'l-'Arab, 15 Cilt. Beyrut: Dâru Sadr.

Îcî, Adudüddîn Abdurrahmân b. Ahmed. Şerḥu'l-'aḍud alâ muhtașari'l-münteha'l-uṣ̂lî. Beyrut: Dâru Kütubi'l-'Illmiyye, 1. Basım, 1421/2000.

Orum, Fatih. Klasik Fıkıh Kaynaklarındaki Kıyas Anlayışının Kur'an Açısından Değerlendirilmesi (Zâhiru'r-Rivâye Örneği). İstanbul: İstanbul Üniversitesi, Sosyal Bilimler Enstitüsü, Doktora Tezi, 2008.

Özen, Şükrü. “Teâruz”. Türkiye Diyanet İslam Ansiklopedisi. 40/208-211. İstanbul: Türkiye Diyanet Vakfı Yayınları, 2011.

Özen, Şükrü. "Tercih”. Türkiye Diyanet İslam Ansiklopedisi. 40/484-487. İstanbul: Türkiye Diyanet Vakfı Yayınları, 2011. 
36 • Kıyas İşleminde Teâruz ve Tercîh

Pezdevî, Ali b. Muhammed, Ușûlü'l-Pezdevî. Mîr Muhammed Muhammed Kütüphane Merkezi.

Razî, Fahruddin Muhammed b. Ömer b. Hüseyin. el-Maḥṣ̂l fî 'ilmi uṣûli'l-fıḳh. 6 Cilt. Müessetü'r-Risâle.

Sadî, Abdülhekim Abdurrahman Ased. Mebâhisu'l-ille fi'l-ḳıyas 'inde'l-uṣûlîn. Beyrut: Dâru'l-Beşâiri'l-İslamiyye, 2. Basım, 1421/200.

Sem'ânî, Ebü'l-Muzaffer Mansûr b. Muhammed b. Abdilcebbar. Kâva'tiu'l-edille fi'luṣûl. 5 Cilt. Beyrut: Dâru Kütubi'l-'Illmiyye, 1. Basım, 1418/1997.

Semerkandî, Alâeddin. Mizânu'l-uṣûl. Katar: 1404/1984.

Serahsî, Ebû Bekir Muhammed b. Ahmed b. Ebî Sehl. Ușûlu's-Serahsî. 2 Cilt. Beyrut: Dâru Kütubi'1-İlmiyye, 1. Basım, 1414/1993.

Sübkî, Tâcuddin Abdulvahhab b. Ali. Cem'u'l-cevâmi'. Beyrut: Dâru Kütubi'l-'İlmiyye, 1424/2002.

Şirâzî, Ebû İshak İbrahim. Şerhu'l-luma'. Beyrut: Dâru ğerbi'l-İslamî, 1. Basım, $1407 / 1988$

Şirâzî, et-Tabṣıra fî uṣûli'l-fiḳh, Dımaşk: Dâru'l-Fikr, 1403/1983.

Zerkeşî, Bedruddin b. Bahâdır b. Abdullah. Bahru'l-muhît fî uṣûli'l-fıḳh. 6 Cilt. Kahire, Dâru's-Safve, 1413/1992. 